\title{
(i) Experimental Investigation on the Performance of DJI Phantom 4 RTK in the PPK Mode for 3D Mapping Open-Pit Mines
}

\author{
Le VAN CANH ${ }^{1, *)}$, Cao XUAN CUONG ${ }^{1)}$, Nguyen QUOC LONG ${ }^{1)}$, \\ Le THI THU HA ${ }^{1)}$, Tran TRUNG ANH ${ }^{2)}$, Xuan-Nam BUI ${ }^{3)}$
}

\footnotetext{
${ }^{1)}$ Department of Mine Surveying, Hanoi University of Mining and Geology, Hanoi; Vietnam; email: levancanh@humg.edu.vn; caoxuancuong@humg.edu.vn; nguyenquoclong@humg.edu.vn; lethithuha@humg.edu.vn

2) Department of Photogrammetry and Remote Sensing, Hanoi University of Mining and Geology, Hanoi, Vietnam; email: trantrunganh@humg.edu.vn

3) Department of Surface Mining, Hanoi University of Mining and Geology, Hanoi, Vietnam; email: buixuannam@humg.edu.vn
}

\section{http://doi.org/10.29227/IM-2020-02-10}

Submission date: 06-03-2020 | Review date: 22-09-2020

\begin{abstract}
Open-pit coal mines' terrain is often complex and quickly and frequently changes. Therefore, topographic surveys of open-pit mines are undertaken on a daily basis. While these tasks are very time-consuming and costly with traditional methods such as total station and GNSS, the unmanned aerial vehicle (UAV) based method can be more efficient. This method is a combination of the "Structure from motion" (SFM) photogrammetry technique and UAV photogrammetry which has been widely used in topographic surveying. With an increasing popularity of RTK-enabled drones, it is becoming even more powerful method. While the important role of ground control points (GCP) in the accuracy of digital surface model (DSM) generated from images acquired by "traditional" UAVs (not RTK-enabled drones) has been proved in many previous studies, it is not clear in the case of RTK-enabled drones, especially for complex terrain in open-pit coal mines. In this study, we experimentally investigated the influence of GCP regarding its numbers and distribution on the accuracy of DSM generation from images acquired by RTK-enabled drones in open-pit coal mines. In addition, the Post Processing Kinematic (PPK) mode was executed over a test field with the same flight altitude. DSM generation was performed with several block control configurations: PPK only, PPK with one GCP, and PPK with two GCPs. Several positions of GCPs were also examined to test the optimal locations for placing GCPs to achieve accurate DSMs. The results show that the horizontal and vertical accuracy given by $P P K$ only were 9.3 and $84.4 \mathrm{~cm}$, respectively. However, when adding at least one GCP, the accuracy was significantly improved in both horizontal and vertical components, with RMSE for XY and Z ranging between 3.8 and $9.8 \mathrm{~cm}$ (with one GCP) and between 3.0 and $5.7 \mathrm{~cm}$ (with two GCPs), respectively. Also, the GCPs placed in the deep areas of the open-pit mine could ensure the cm-level accuracy.
\end{abstract}

Keywords: unmanned aerial vehicle, post processing kinematic, digital surface model, open-pit mines

\section{Introduction}

Mine surveying is one of the most critical tasks in openpit mines (Nguyen Quoc Long et al., 2019). Surveying engineering, topological survey, and volumetric computation are undertaken on a daily basis (Le Van Canh et al., 2020). Conventional methods such as total station and global navigation satellite system (GNSS) have been commonly used in mine surveying. These methods are direct survey with an ability of achieving the cm-level accuracy (Dieu Tien Bui et al., 2017). However, they are limited in several aspects, such as time-consuming and labour-intensive work. Other alternatives and advanced methods such as terrestrial laser scanning (TLS) and airborne Light Detection and Ranging (LiDAR) have recently been available. Specifically, both TLS and LiDAR are able to provide much higher spatial resolution with equivalent accuracy to that of traditional ones. However, there are several limiting factors for operationalizing LiDAR including high cost (Chiara et al., 2018; C. H. Hugenholtz et al., 2013) and high vertical errors in areas with complex environments (Carrivick et al., 2016). TLS which is a more affordable alternative to airborne LiDAR with greater operational flexibility as TLS units are typically mounted on tripods (C. H. Hugenholtz et al., 2013; Nguyen Quoc Long et al., 2018; Nguyen Viet Nghia et al., 2019), but its data acquisition and post-processing require a considerable amount of time (C. H. Hugenholtz et al., 2015; Taddia et al., 2020). For the complex terrain of openpit mines, it often requires many laser scanning stations to avoid any loss in the generated 3D spatial models. Considering the aforementioned aspects, it is desirable to have an optimal method which could inexpensively provide data with high spatial resolution, reasonable coverage, and greater operational flexibility than TSL and LiDAR.

Unmanned aerial vehicles (UAVs) are a valid and effective alternative surveying technique for topographic reconnaissance and volumetric calculation, thanks to the miniaturization and cost reduction of GNSS receivers, internal measurement unit (IMU), computers, and remote sensing sensors. In addition, thanks to the use of multiple flights and of single tilt-shift lenses to improve data accuracy, the spatial information density and accuracy of UAV photogrammetry can be comparable to that of airborne LiDAR and TLS (Gong et al., 2019). Normally, UAV imagery is geo-referenced via ground control points (GCPs), which are placed on the study area and measured using GNSS receivers or total stations. This procedure is called indirect geo-referencing. Also, the accuracy of DSM increases asymptotically with an increasing number of 
Tab 1. Several studies on UAV applications on building DSM with their study areas

Tab. 1. Kilka badań dotyczących zastosowań BSP w budowaniu NMP wraz z ich obszarami badawczymi

\begin{tabular}{|l|l|l|l|}
\hline & Authors and publishing year & $\begin{array}{l}\text { Flight height/ Ground } \\
\text { Sample Distance (GSD) }\end{array}$ & Kind of Terrain \\
\hline 1 & $\begin{array}{l}\text { Fazeli, Samadzadegan, and Dadrass } \\
\text { Javan (2016) }\end{array}$ & $120 \mathrm{~m} / 2.38 \mathrm{~cm}$ & Agricultural area \\
\hline 2 & Zhang et al. (2019) & $\begin{array}{l}20,35 \text { and } 45 \mathrm{~m} / 0.6,0.5 \text { and } \\
1.3 \mathrm{~cm}\end{array}$ & $\begin{array}{l}\text { Agricultural area; the maximum difference in elevation: } \\
3 \text { m; Slope of 1 degree }\end{array}$ \\
\hline 3 & $\begin{array}{l}\text { Taddia, Stecchi, and Pellegrinelli } \\
(2020)\end{array}$ & $80 \mathrm{~m} / 2 \mathrm{~cm}$ & Flat coastal area \\
\hline 4 & Ekaso, Nex, and Kerle (2020) & $40 \mathrm{~m} / 1.33 \mathrm{~cm}$ & Flat area \\
\hline 5 & Forlani et al. (2018) & $90 \mathrm{~m} / 2.3 \mathrm{~cm}$ & $\begin{array}{l}\text { The southern part of the Parma University's campus, the } \\
\text { vertical range of 6-35 m }\end{array}$ \\
\hline 6 & $\begin{array}{l}\text { Stroner, Urban, Reindl, Seidl, and } \\
\text { Brouček (2020) }\end{array}$ & $100 \mathrm{~m} / 2.8 \mathrm{~cm}$ & Urban and flat Rural \\
\hline 7 & (Wiącek \& Pyka, 2019) & $155-230 \mathrm{~m} / 2-3 \mathrm{~cm}$ & Flat area \\
\hline 8 & Dinkov, 2019 & $45 \mathrm{and} 75 \mathrm{~m} / 1.27-2.08 \mathrm{~cm}$ & Park area, the maximum difference in elevation: 27 m \\
\hline 9 & (Thiel et al., 2020) & $100 \mathrm{~m} / 2.8 \mathrm{~cm}$ & Pine-Dominated Forest in Central Germany \\
\hline 10 & (Dinkov \& Kitev, 2020) & $65 \mathrm{~m} / 1.78 \mathrm{~cm}$ & $\begin{array}{l}\text { A rural area on the land of the village of Plana, Sofia } \\
\text { Municipality, slope of } 8.3 \%\end{array}$ \\
\hline
\end{tabular}

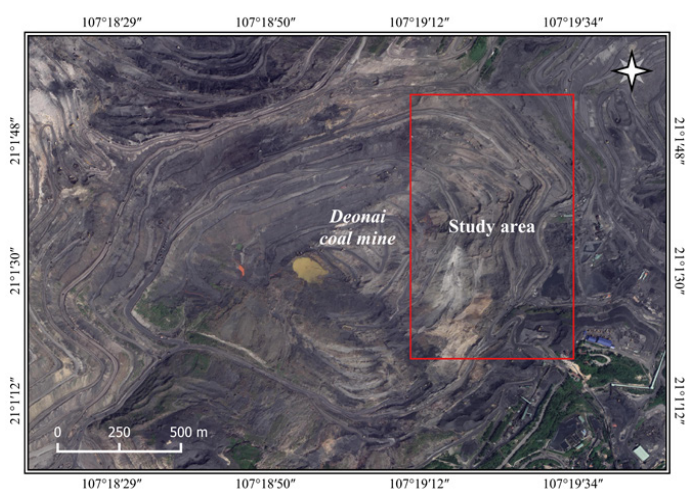

Fig. 1. Location of the study area

Rys 1. Lokalizacja badanego obszaru

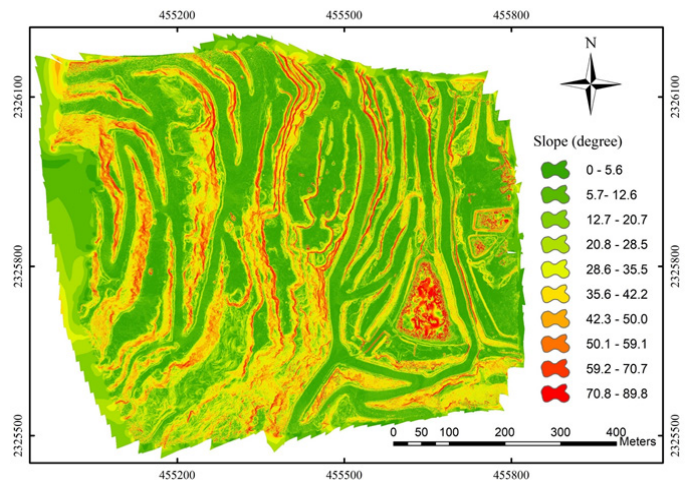

Fig. 2. Slope map of the case study in the Deo Nai coal mine Rys. 2. Mapa nachylenia badanego terenu na obszarze kopalni Deo Nai

GCPs until a certain density of GCPs is reached (Gindraux et al., 2017). It is shown that the cm-level accuracy can be achieved with no less than five GCPs in most terrain conditions (Lee \& Choi, 2015; Nguyen Quoc Long et al., 2019; Siebert \& Teizer, 2014) and this requires even more than ten GCPs with complex terrain such as that in open-pit mining sites(Dieu Tien Bui et al., 2017). However, GCP acquisition is impeded by site access difficulties or hazardous circumstances (Ekaso et al., 2020), so a large number of GCPs could reduce the mine surveying efficiency.

Recently, small and low-cost UAVs with the integration of high-quality GNSS and IMU measurements or RTK enabled UAVs have been increasingly available. They provide a new approach of geo-referencing for UAV imagery called direct geo-referencing, which is the determination of both the absolute positioning and the camera orientation with reasonable accuracy and no GCPs. However, to satisfy the accuracy requirement of surveying work (the centimetre-level positioning accuracy), several studies suggested the use of some GCPs to get the same accuracy level of GCP based geo-referencing or indirect geo-referencing, and more importantly, to prevent biases from false ambiguity fixing camera calibration errors (Gianfranco et al., 2018; C. Hugenholtz et al., 2016; Mian et al., 2015).

While there have been many studies focusing on applications of RTK enabled UAVs on flat terrain (see Tab 1), not many studies examine their ability at open-pit coal mines. In this article, we investigated the PPK approach for the recon- 


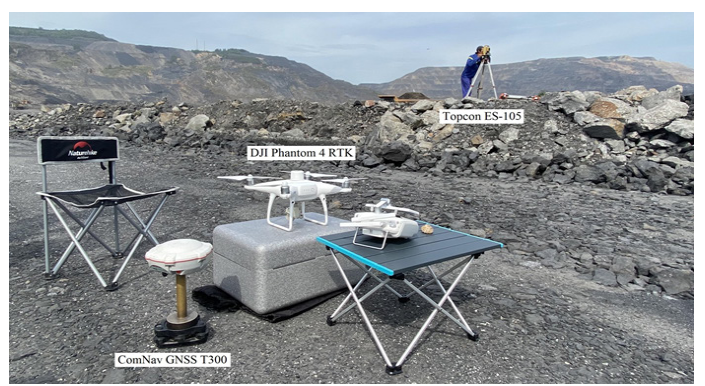

Fig. 3. Instruments for the study

Rys. 3. Experymentalne wyposażenia

Tab 1. Several studies on UAV applications on building DSM with their study areas

Tab. 1. Kilka badań dotyczących zastosowań BSP w budowaniu NMP wraz z ich obszarami badawczymi

\begin{tabular}{|l|l|l|}
\hline \multicolumn{1}{|c|}{ Specifications } & \multicolumn{1}{|c|}{ D-RTK 2 } & \multicolumn{1}{c|}{ GNSS ComNav T300 } \\
\hline & GPS: L1 C/A, L2, L5 & GPS: L1,L2,L2C,L5; \\
& BEIDOU: B1, B2, B3 & BeiDou: B1, B2, B3; \\
& GLONASS: F1, F2 & GLONASS: F1, F2 \\
\hline \multirow{3}{*}{ Tracked satellite signals } & Galileo: E1, E5A, E5B & Real Time Kinematic \\
& Real Time Kinematic & Horizontal $: 1 \mathrm{~cm}+0.5 \mathrm{ppm}(\mathrm{RMS})$ \\
& Horizontal $: 1 \mathrm{~cm}+1 \mathrm{ppm}(\mathrm{RMS})$ & Vertical $: 2 \mathrm{~cm}+0.5 \mathrm{ppm}(\mathrm{RMS})$ \\
\hline & Vertical $: 2 \mathrm{~cm}+1 \mathrm{ppm}(\mathrm{RMS})$ & $1 \mathrm{~Hz}, 2 \mathrm{~Hz}, 5 \mathrm{~Hz}$ and $10 \mathrm{~Hz}$ \\
\hline Positioning Update Rate & $1 \mathrm{~Hz}, 2 \mathrm{~Hz}, 5 \mathrm{~Hz}, 10 \mathrm{~Hz}$ and $20 \mathrm{~Hz}$ & $<2 \mathrm{~s}$ \\
\hline Recapture Time & $<1 \mathrm{~s}$ & $>99.9 \%$ \\
\hline Initialization Reliability & $>99.9 \%$ & RTCM $2 . \mathrm{X} / 3 . \mathrm{X}$ and CMR \\
\hline Differential Data Format & RTCM $2 . \mathrm{X} / 3 . \mathrm{X}$ & \\
\hline
\end{tabular}
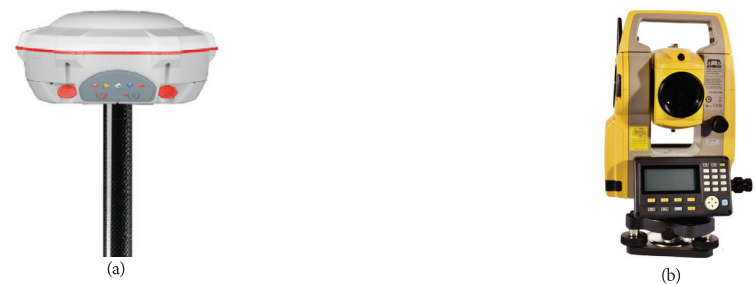

Fig. 4. (a) ComNav T300 GNSS Receiver; (b) Topcon ES 105 Total station Rys. 4. (a) Odbiornik ComNav T300 GNSS; (b) Tachimetr elektroniczny Topcon ES 105
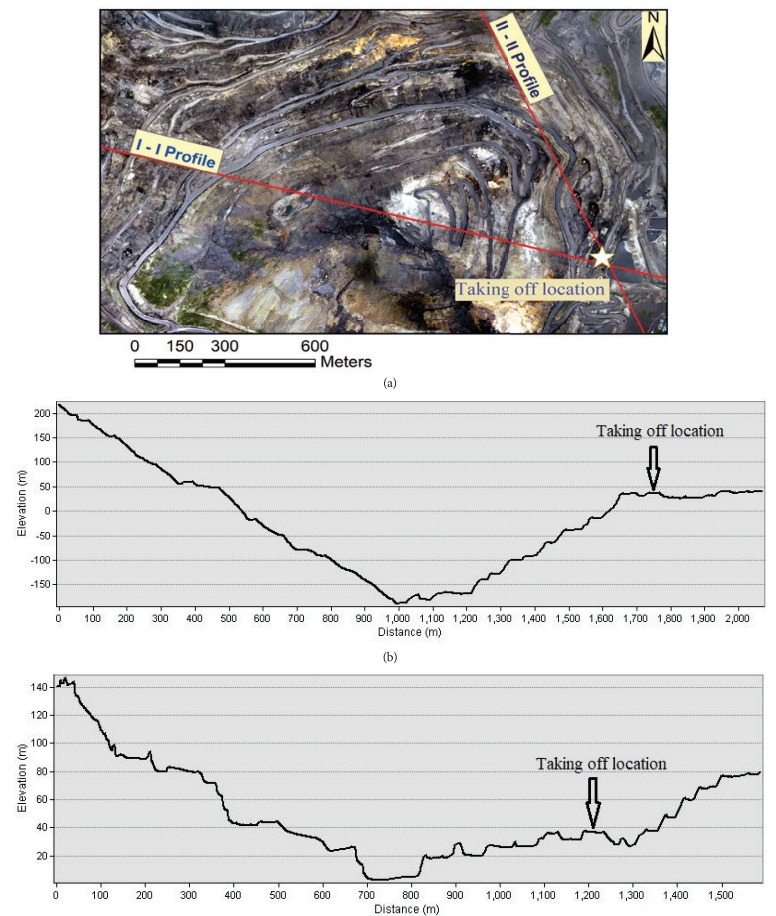

Fig. 5. (a) Orthophoto of Deo Nai coal mine; (b) I-I profile; (c) II-II profile Rys. 5. (a) Ortofotomapa kopalni Deo Nai; b) przekrój I-I; c) przekrój II-II 

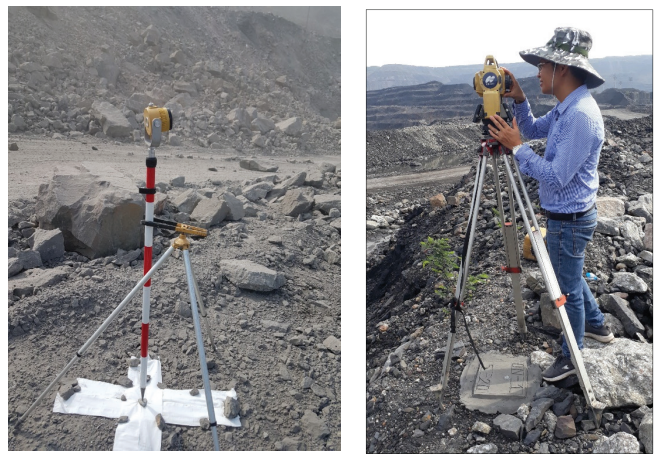

Fig. 6. An example of a GCP on the test site and measurement by a total station Rys. 6. Przykład GCP na terenie i pomiar tachimetrem elektronicznym

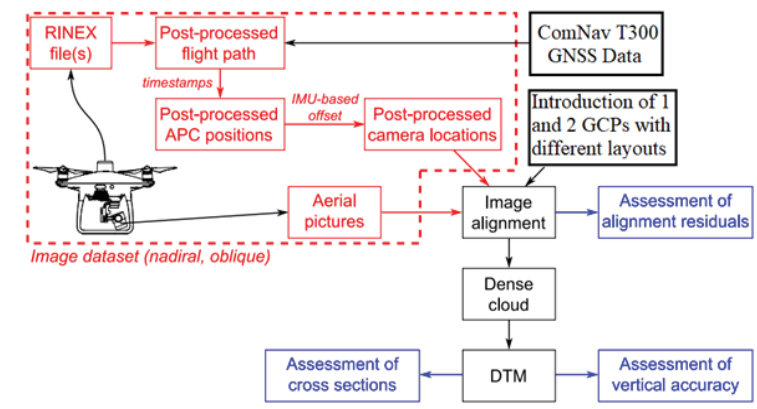

Fig. 7. Flowchart of data processing (modified from (Taddia et al., 2020))

Rys. 7. Schemat blokowy przetwarzania danych (zmodyfikowany na podstawie (Taddia et al., 2020))

struction of photogrammetric models and DSM of a working site located in an open-pit coal mine through the use of Receiver Independent Exchange Format (RINEX) files from a DJI Phantom 4 RTK and a third party GNSS receiver. In addition, we seek the answers for the questions: whether we need any GCPs, and what is their layout in order to achieve the centimetre-level accuracy.

\section{Study area}

In this study, the Deo Nai open-pit coal mine is selected for the experimental site (Fig 1). The mine located in northern Vietnam is one of the largest open-pit coal mines in the country. According to the permission decision of exploitation (2817/GP-BTNMT) issued by the Ministry of Natural Resources and Environment in 2008, the mine covers a total area of six $\mathrm{km} 2$ with proven reserves of 42.5 million ton and produces 2.5 million ton per year (Xuan-Nam et al., 2020). The Deo Nai open-pit coal mine is planned to close in the year of 2025 when it reaches to the minimum extraction elevation of $-345 \mathrm{~m}$ above from the sea level (amsl). During the study time, the minimum elevation of excavation was $-198 \mathrm{~m}$.

The site mapped in this work is presented by a red rectangle sized $750-650 \mathrm{~m}$. In this area, the elevation of terrain changes from $-190 \mathrm{~m}$ to $+60 \mathrm{~m}$. Fig 2 illustrates how complex the test site is. In addition, this site was the working area of the mine as several excavators and drills were working.

\section{Data acquisition}

\subsection{Preparation of instruments}

The aerial data acquisition was undertaken using a recent model of a RTK quadcopter produced by DJI: the Phantom 4 RTK (Fig 3). It is noted that this model is one of the most ver- satile and easy to use UAVs (Taddia et al., 2020). In addition, the DJI Phantom 4 RTK is a compact and lightweight UAV equipped with a multi-constellation multi-frequency GNSS receiver, which is able to receive GPS, GLONASS, Galileo, and Beidou signals. Raw GNSS data is sampled with a rate of $5 \mathrm{~Hz}$ and stored in a RINEX file v.3.02. All flight missions are automatically carried out with the continuous record of flight paths. Therefore, the Phantom 4 RTK is able to perform the kinematic GNSS technique with the cm-level accuracy and so allows direct geo-referencing.

In the market, DJI offers a Phantom 4 RTK with the D-RTK 2 mobile station (https://www.dji.com). However, in this study, we employed a GNSS ComNav T300 for the base station (Fig 4a and Tab 2). This allows us to evaluate the performance of the Phantom 4 RTK with a third party GNSS receiver. As the limitation of connection between our Phantom 4 RTK and GNSS ComNav T300, we used the PPK mode in this study.

\subsection{UAV imaging surveys}

The flight planning is one of the most important tasks and needs to be seriously considered in terms of safety, the highest precision, and effectiveness. The top priority could be the safety of flying UAV, so we chose the taking off location and flight height that ensure the drone flying at the higher altitude compared to all peaks within the test site (Fig 5). On both the I-I and II-II profiles, the highest points of $250 \mathrm{~m}$ and $150 \mathrm{~m}$ were not in the flying test site, ensuring the safety of flying UAV.

Flight planning was created with the following parameters: the flight height of $100 \mathrm{~m}$ from the ground level, with a ground sample distance (GSD) of about $2.74 \mathrm{~cm} /$ pixel, $75 \%$ 


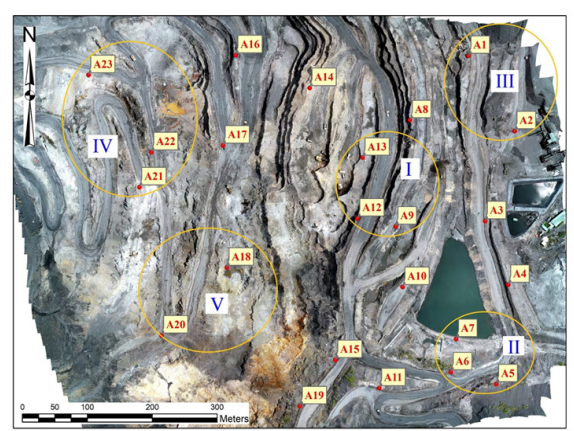

Fig. 8. Points for GCPs and CPs and Distribution as groups of points Rys. 8. Punkty GCP, CP oraz rozmieszczenie grupy punktów
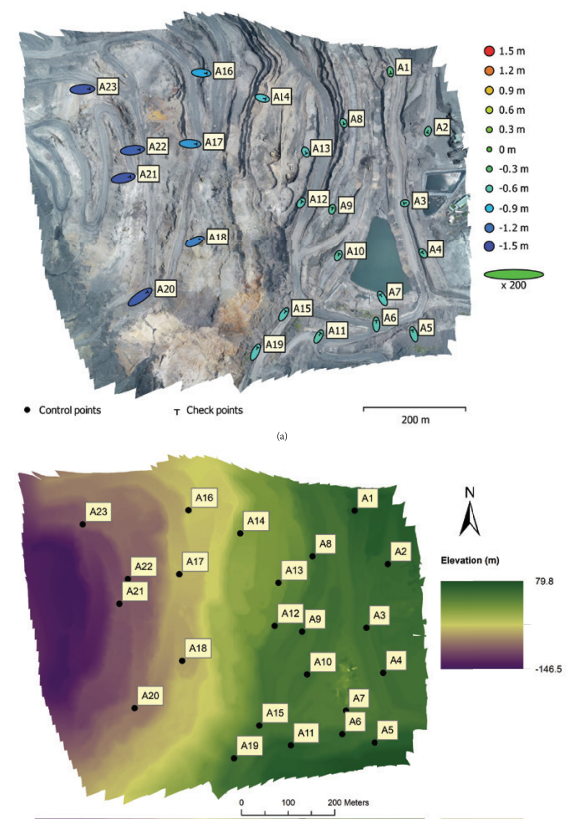

Fig. 9. (a) GCP locations and error estimates (created by Agisoft Metashape), (b) Digital surface model of the study area. Z error is represented by ellipse colour. X, Y errors are represented by ellipse size

Rys. 9. (a) Lokalizacje punktów kontrolnych i szacunki błędów (stworzone przez Agisoft Metashape), (b) Numeryczny model powierzchni badanego obszaru. Błąd Z jest reprezentowany przez kolor elipsy. Błędy X, Y są reprezentowane przez rozmiar elipsy

both forward and side overlap at ground level, and an average flying speed of $7 \mathrm{~m} / \mathrm{s}$. The flights were executed in summer 2020, between 9 a.m. and 10:10 a.m., which was sunny time. There were three blocks consisting of 21 strips, with a total number of about 364 images.

\subsection{Ground control point establishment}

GCPs and checkpoints (CPs) for block orientation quality were marked on the ground by crosses (Fig 6). Their coordinates $(\mathrm{x}, \mathrm{y}, \mathrm{z})$ in VN2000 coordinate system with universal transverse Mercator (UTM) projection at 3-degree zone were measured right before the flights, at least three times each, with a Topcon ES 105 total station (Fig 4.B) (angular accuracy is 5 " and distance accuracy is $2 \mathrm{~mm}+2 \mathrm{ppm}$ ) and the available horizontal and vertical surveying network at the mine area. Accordingly, a total of 23 points was established for the test area of $0.542 \mathrm{~km} 2$ at the Deo Nai open-pit coal mine.

\section{Methods}

\subsection{Post-Processing Kinematic of RINEX Files}

In this work, a RINEX file of each automatic flight mis- sion was used in post-processing mode using GNSS observations of a base station. The base station was set within the test site, and the ComNav T300 receiver was able to receive signals from GPS, GLONASS, BEIDOU, and GALILEO with a sampling rate of $5 \mathrm{~Hz}$. The software used for processing was RTKLib 2.4.3. There are several steps taken with RTKLib including uploading RINEX files, broadcast navigation file which is NASA's daily GPS broadcast ephemeris data available at NASA's CCDIS website (https://cddis.nasa.gov).

\subsection{Structure from Motion (SfM) procedure and Agisoft Metashape Software}

Typically, the image processing using the SfM procedure consists of five steps: (i) photo alignment; (ii) bundle block adjustment; (iii) optimization, (iv) 3D surface reconstruction, (v) generation of Digital Surface Model (DSM) (Dieu Tien Bui et al., 2017).

In this study, the SfM analysis was performed with the Agisoft Metashape, which is a commercial product developed by Agisoft LLC Company. A comparative analysis of different common UAV processing software showed that this software 
Tab. 3. Errors and RMSE in X, Y, XY, Z, and XYZ of checkpoints

Tab. 3. Błędy średnie składowych współrzędnych X, Y, XY, Z i XYZ punktów kontrolnych

\begin{tabular}{|c|c|c|c|c|c|}
\hline Points & X error $(\mathrm{cm})$ & Y error $(\mathrm{cm})$ & XY error $(\mathrm{cm})$ & Z error $(\mathrm{cm})$ & Total $(\mathrm{cm})$ \\
\hline A 1 & 0.6 & -3.9 & 3.9 & -41.7 & 41.9 \\
\hline A 2 & -0.9 & -3.2 & 3.3 & -51.9 & 52 \\
\hline A 3 & -2 & -0.3 & 2 & -59.3 & 59.3 \\
\hline A 4 & -2.2 & 3 & 3.7 & -55.7 & 55.8 \\
\hline A 5 & -2.6 & 8.3 & 8.7 & -61.3 & 61.9 \\
\hline A 6 & -0.3 & 7.6 & 7.6 & -61.8 & 62.3 \\
\hline A 7 & -4 & 7.6 & 8.6 & -66.4 & 66.9 \\
\hline A 8 & 1.1 & -2.4 & 2.7 & -55.9 & 56 \\
\hline A 10 & 0.8 & 3.4 & 3.5 & -51.4 & 51.5 \\
\hline A 11 & 1.8 & 3.7 & 4.1 & -55.5 & 55.6 \\
\hline A 12 & 3.9 & 6.7 & 7.7 & -56.4 & 56.9 \\
\hline A 13 & 2.3 & 3.3 & 4 & -63.4 & 63.5 \\
\hline A 14 & 1.5 & -3 & 3.4 & -68.6 & 68.6 \\
\hline A 15 & 6.7 & -1.8 & 6.9 & -77.2 & 77.5 \\
\hline A 16 & 4.1 & 6.4 & 7.6 & -63.8 & 64.2 \\
\hline A 17 & 11 & -0.7 & 11 & -97.6 & 98.2 \\
\hline A 18 & 12.9 & -0.5 & 12.9 & -105.2 & 106 \\
\hline A 19 & 9.8 & 4.5 & 10.8 & -113.2 & 113.7 \\
\hline A 20 & 4.5 & 9.4 & 10.4 & -66.9 & 67.7 \\
\hline A 21 & 15 & 10.4 & 18.3 & -133.1 & 134.3 \\
\hline A 22 & 14.2 & 2.5 & 14.4 & -137.4 & 138.1 \\
\hline A 23 & 14.6 & 1.5 & 14.7 & -129.6 & 130.4 \\
\hline RMSE & 14.8 & 0.8 & 14.8 & -136.5 & 137.3 \\
\hline
\end{tabular}

Tab. 3. Errors and RMSE in X, Y, XY, Z, and XYZ of checkpoints

Tab. 3. Błędy średnie składowych współrzędnych X, Y, XY, Z i XYZ punktów kontrolnych

\begin{tabular}{|c|c|c|c|}
\hline Area & GCP & Largest RMSE for XYZ (cm) & $\begin{array}{c}\text { Location of least accurate } \\
\text { CPs }\end{array}$ \\
\hline \multirow{4}{*}{ I } & A12 & 21.4 & \multirow{4}{*}{ In area $\mathrm{V}$} \\
\hline & A13 & 26.7 & \\
\hline & A9 & 31.3 & \\
\hline & Average & 26.4 & \\
\hline \multirow{4}{*}{ II } & A5 & 21.1 & \multirow{4}{*}{ In area IV } \\
\hline & $\mathrm{A} 6$ & 16.5 & \\
\hline & A7 & 12.1 & \\
\hline & Average & 16.5 & \\
\hline \multirow{3}{*}{ III } & A1 & 39.4 & \multirow{3}{*}{ In $\operatorname{area} \mathrm{V}$} \\
\hline & A2 & 27.7 & \\
\hline & Average & 33.5 & \\
\hline \multirow{4}{*}{ IV } & $\mathrm{A} 21$ & 11.2 & \multirow{4}{*}{ In area II } \\
\hline & A22 & 10.8 & \\
\hline & A23 & 11.1 & \\
\hline & Average & 11.0 & \\
\hline \multirow{3}{*}{$\mathrm{V}$} & A18 & 10.2 & \multirow{3}{*}{ In area I } \\
\hline & A20 & 14.3 & \\
\hline & Average & 12.3 & \\
\hline
\end{tabular}

Tab. 3. Errors and RMSE in X, Y, XY, Z, and XYZ of checkpoints

Tab. 3. Błędy średnie składowych współrzędnych X, Y, XY, Z i XYZ punktów kontrolnych

\begin{tabular}{|c|c|c|l|}
\hline \multirow{2}{*}{ Area } & GCP & $\begin{array}{c}\text { Largest RMSE for } \\
\mathbf{X Y Z} \\
\mathbf{( c m )}\end{array}$ & \multicolumn{1}{|c|}{ Location of least accurate CPs } \\
\hline II-IV & A5 and A23 & 11.8 & In area III \\
\hline II-III & A1 and A5 & 12.3 & In area V \\
\hline III-IV & A1 and A23 & 13.6 & In area II \\
\hline IV-V & A20 and A23 & 8.5 & In area III \\
\hline
\end{tabular}

outperforms other software in terms of accuracy (Sona, Pinto, Pagliari, Passoni, \& Gini, 2014). The performance of block orientation and dense stereo matching is carried out using a multi-image approach. Moreover, the software offers users the photogrammetric process with a high level of automation. However, users can define several parameters. In this work, the following parameters were optimized: $\mathrm{f}, \mathrm{Cx}, \mathrm{Cy}, \mathrm{B} 1, \mathrm{~B} 2$, K1, K2, K3, K4, P1, and P2 (Agisoft LLC, 2019).

\subsection{Control configurations}

To test whether the direct geo-referencing needs additional GCPs so as to achieve the cm-level accuracy under the terrain condition of open-pit coal mines, several experiments were conducted by changing the block control configuration. The following configurations were set up: PPK only, PPK with 1 GCP, and PPK with 2 GCPs. In addition, to determine how the position of GCPs on the test site influences the accuracy, several scenarios with different layouts of GCPs were made. In each scenario of PPK with 1 or 2 GCPs, cross-validation was used. We divided the test site into five main areas, namely I, II, III, IV, and V, where GCPs or CPs were located (Fig 8).

For the scenario of PPK +1 GCP, we selected one point from each area as the GCP, while the remaining targets were then used as CPs, and the bundle adjustment processing was repeated 13 times as there were 13 cases. For the scenario of PPK + 2 GCPs, we selected points from different areas but 
Tab. 6. Errors and RMSE in X, Y, XY, Z, and XYZ of checkpoints in all test cases

Tab. 6. Błędy i RMSE w X, Y, XY, Z i XYZ punktów kontrolnych we wszystkich przypadkach

\begin{tabular}{|c|c|c|c|c|c|c|}
\hline Area & GCP & $\begin{array}{c}\text { X error } \\
\text { (cm) }\end{array}$ & $\begin{array}{l}\text { Y error } \\
\text { (cm) }\end{array}$ & $\begin{array}{l}\text { XY error } \\
\text { (cm) }\end{array}$ & $\begin{array}{l}\text { Z error } \\
\text { (cm) }\end{array}$ & $\begin{array}{l}\text { XYZ error } \\
\text { (cm) }\end{array}$ \\
\hline \multicolumn{2}{|c|}{ PPK without GCP } & 7.8 & 5.0 & 9.3 & 84.4 & 84.9 \\
\hline \multicolumn{7}{|c|}{ PPK with one GCP } \\
\hline \multirow{3}{*}{ I } & A9 & 8.4 & 5.1 & 9.8 & 14.1 & 17.1 \\
\hline & $\mathrm{A} 12$ & 8.3 & 5.3 & 9.8 & 6.2 & 11.6 \\
\hline & $\mathrm{A} 13$ & 7.2 & 5.6 & 9.1 & 10.2 & 13.7 \\
\hline \multirow{3}{*}{ II } & A5 & 5.5 & 3.2 & 6.4 & 11.9 & 13.5 \\
\hline & A6 & 5.6 & 3.2 & 6.4 & 8.2 & 10.4 \\
\hline & A7 & 5.6 & 2.9 & 6.3 & 4.7 & 7.8 \\
\hline \multirow{2}{*}{ III } & $\mathrm{A} 1$ & 6.6 & 5 & 8.3 & 20.2 & 21.8 \\
\hline & $\mathrm{A} 2$ & 6.9 & 5 & 8.5 & 11.4 & 14.2 \\
\hline \multirow{3}{*}{ IV } & A21 & 2.8 & 2.9 & 4.0 & 4.4 & 6 \\
\hline & A22 & 2.5 & 2.8 & 3.8 & 4.4 & 5.8 \\
\hline & A23 & 3.7 & 3.3 & 5.0 & 4.3 & 6.6 \\
\hline \multirow{2}{*}{$\mathrm{V}$} & $\mathrm{A} 18$ & 2.7 & 3 & 4.0 & 4.3 & 5.9 \\
\hline & $\mathrm{A} 20$ & 2.5 & 3.2 & 4.1 & 5.9 & 7.1 \\
\hline \multicolumn{7}{|c|}{ PPK with two GCPs } \\
\hline II-IV & $\mathrm{A} 5$ and $\mathrm{A} 23$ & 4.1 & 2.0 & 4.6 & 4.7 & 6.6 \\
\hline II-III & $\mathrm{A} 1$ and $\mathrm{A} 5$ & 5.3 & 2.3 & 5.7 & 3.1 & 6.5 \\
\hline III-IV & $\mathrm{A} 1$ and $\mathrm{A} 23$ & 3.0 & 3.3 & 4.5 & 5.1 & 6.8 \\
\hline IV-V & $\mathrm{A} 20$ and $\mathrm{A} 23$ & 2.1 & 2.1 & 3.0 & 3.5 & 4.6 \\
\hline
\end{tabular}

excluding the area I as GCPs, while the remaining targets were then used as CPs, and the bundle adjustment processing was repeated four times as there were 4 cases. The accuracy assessment was based on the mean error of the cross-validation. The influence of GCPs position in the study area was also analyzed.

\subsection{Accuracy assessment}

In order to evaluate the accuracy of DSM (or Digital elevation model - DEM) generated by different configurations, the Root Mean Square Error (RMSE) for X, Y, Z, and XY were calculated, using the following equations:

$$
\begin{aligned}
& R M S E_{X}=\sqrt{\left[(1 / n) \sum_{i=1}^{n}\left(X_{D E M}-X_{G C P i}\right)^{2}\right]} \\
& R M S E_{Y}=\sqrt{\left[(1 / n) \sum_{i=1}^{n}\left(Y_{D E M}-Y_{G C P i}\right)^{2}\right]} \\
& R M S E_{X Y}=\sqrt{\left[R M S E_{X}^{2}+R M S E_{Y}^{2}\right]} \\
& R M S E_{Z}=\sqrt{\left[(1 / n) \sum_{i=1}^{n}\left(Z_{D E M}-Z_{G C P i}\right)^{2}\right]} \\
& R M S E_{X Y Z}=\sqrt{\left[R M S E_{X}^{2}+R M S E_{Y}^{2}+R M S E_{Z}^{2}\right]}
\end{aligned}
$$

where $\mathrm{n}$ is a number of GCP $\mathrm{X}_{\mathrm{GCP}}$ and $\mathrm{X}_{\mathrm{DEM}}$ are the $\mathrm{X}$-coordinate component of GCP and corresponding coordinate in DEM, respectively; $\mathrm{Y}_{\mathrm{GCPi}}$ and $\mathrm{Y}_{\mathrm{DEM}}$ are the Y-coordinate component of GCP and corresponding coordinate in DEM, respectively; $\mathrm{Z}_{\mathrm{GCPi}}$ and $\mathrm{Z}_{\mathrm{DEM}}$ are the $\mathrm{Z}$-coordinate component of GCP and corresponding coordinate in DEM, respectively.

\section{Results and Discussions}

\subsection{Accuracy of direct geo-referencing (PPK only)}

Tab 3 shows that PPK only provided horizontal and vertical RMSE of 9.3 and $84.4 \mathrm{~cm}$, respectively. It is observed that while the horizontal accuracy meets the mining survey-grade requirement, the vertical accuracy fails as it was at the decimeter-level accuracy (Vietnam Standards and Quality Institute, 2015). Specifically, the smallest and greatest RMSE for XY were $2.0 \mathrm{~cm}$ (A3) and $18.3 \mathrm{~cm}$ (A20). Fig 9a and b illustrate that all checkpoints with great RMSE for both horizontal and vertical components were located in deep areas. It is observed that the deeper the area is, the less accurate the DSM is.

\subsection{Accuracy of PPK with one GCP}

For PPK with one GCP, the results are presented in Tabs 4 and 6. In general, when adding one GCP, the accuracy of DSM generated was significantly improved. For example, with the least accurate point in the PPK only case (A20), its vertical RMSE decreased by $84 \%$ from $134.3 \mathrm{~cm}$ to $21.5 \mathrm{~cm}$.

Regarding the influence of GCP distribution, Tab 4 shows that when the GCP was selected from the area I, CPs with the largest RMSE for XYZ can be found in the area V with an average RMSE of $26.4 \mathrm{~cm}$. For the cases of GCPs selected in area II, the least accurate CPs were found in area IV with the average RMSE of $16.5 \mathrm{~cm}$. For the cases of GCPs located in the areas III, IV, and V, the least accurate CPs can be found in $\mathrm{V}$, II, and I, with the average RMSE of 33.5, 11.0 , and $12.3 \mathrm{~cm}$, respectively. It can be observed that the area $\mathrm{V}$ was the most sensitive to the position of GCP as checkpoints in this area were least accurate, while the area IV and V were the most suitable areas for placing a GCP. In addition, the closer to the GCP, the more accurate the point is.

\subsection{Accuracy of PPK with 2 GCPs}

For the scenario of PPK with 2 GCPs, Tab 5 shows that when GCPs were chosen from the areas II and IV, CPs with the largest RMSE for XYZ can be found in area III with an average RMSE of $11.8 \mathrm{~cm}$. For the cases of GCPs selected in the areas II and III, the least accurate checkpoint was found in the area $\mathrm{V}$ with an average RMSE of $12.3 \mathrm{~cm}$. For the case of GCPs located in the areas III and IV, the least accurate checkpoints can be found in area II with an average RMSE of 13.6 $\mathrm{cm}$. Finally, for the case of IV and V, the result showed that the least accurate checkpoints could be found in area III with an average RMSE of $8.5 \mathrm{~cm}$.

In all scenarios of PPK with two GCPs, the results show that the accuracy of DSMs was significantly improved with RMSE for XY, and Z decreased from 9.8 to $3.0 \mathrm{~cm}$ and from 20.2 to $3.1 \mathrm{~cm}$, respectively (Tab 6).

\section{Conclusions}

In this study, we conducted an experimental investigation on the repeatability of DSM generation for an open-pit coal mine using a DJI Phantom 4 RTK with a ComNav T300 GNSS receiver as the base station in the PPK mode. The flight height of $100 \mathrm{~m}$ was set in order to be safe and achieve the high resolution (a GSD of $2.7 \mathrm{~cm}$ ). PPK processing performed with 
the RTKLib 2.4.3 software provided the position of camera stations with the $\mathrm{cm}$-level accuracy. It can be concluded that a DJI Phantom 4 RTK with a ComNav T300 receiver can work together in the PPK mode to achieve accurate camera station positions.

For the case of PPK only, the horizontal accuracy was much higher than vertical accuracy with RMSE of $9.3 \mathrm{~cm}$ and $84.4 \mathrm{~cm}$, respectively. This means that considering the accuracy requirement of mine surveying, the PPK only mode is not recommended.

In all of the tests that were conducted, adding at least one GCP to the camera stations successfully removed most

of the bias. The horizontal accuracy was in the $3.8-9.8$ $\mathrm{cm}$ RMSE range (with one GCP) and in the $3.0-5.7 \mathrm{~cm}$ RMSE range (with two GCPs). Also, the vertical accuracy was significantly improved with RMSE for $\mathrm{Z}$ of $4.3 \mathrm{~cm}$ (with one GCP), and $3.1 \mathrm{~cm}$ (with two GCPs). This result showed a similarity to Gianfranco et al. (2018).

In consideration of GCP distribution in open-pit coal mines, with one GCP, it is recommended that the GCP should be placed in areas with low elevations as this ensures the accuracy in both horizontal and vertical directions in these areas. This is also true for the case of two GCPs.

\section{Acknowledgement}

This study is funded by Hanoi University of Mining and Geology through the research project T20-06. The authors would like to thank Deo Nai coal mine and Cam Pha mine geology company for supports with data collection.

\section{Literatura - References}

1. Agisoft LLC. (2019). Agisoft Metashape User Manual: Professional Edition, Version 1.5.

2. Carrivick, J., Smith, M., \& Quincey, D. (2016). Structure from Motion in the Geosciences (index) (pp. 195-197).

3. Chiara, T., Andrea, B., Federico, C., Ugo, C., Franco, M., Alessandro, Z., \& Beniamino, G. (2018). Development and Performance Assessment of a Low-Cost UAV Laser Scanner System (LasUAV). Remote Sensing, 10(7), 1094. doi:10.3390/rs10071094

4. Dieu Tien Bui, Nguyen Quoc Long, Bui Xuan Nam, Nguyen Viet Nghia, Pham Van Chung, Le Van Canh, ... Bjørn Kristoffersen. (2017). Lightweight Unmanned Aerial Vehicle and Structure-from-Motion Photogrammetry for Generating Digital Surface Model for Open-Pit Coal Mine Area and Its Accuracy Assessment. International Conference on Geo-Spatial Technologies and Earth Resources, 17-33.

5. Dinkov, D. (2019). A Low Cost Method UAV-PPK -Accuracy and Application.

6. Dinkov, D., \& Kitev, A. (2020). Advantages, disadvantages and applicability of GNSS post-processing kinematic (PPK) method for direct georeferencing of UAV images.

7. Ekaso, D., Nex, F., \& Kerle, N. (2020). Accuracy assessment of real-time kinematics (RTK) measurements on unmanned aerial vehicles (UAV) for direct geo-referencing. Geo-spatial Information Science, 1-17. doi:10.1080/10095 020.2019 .1710437

8. Fazeli, H., Samadzadegan, F., \& Dadrass Javan, F. (2016). Evaluating the potential of RTK-UAV for automatic point cloud generation in 3D rapid mapping. ISPRS - International Archives of the Photogrammetry, Remote Sensing and Spatial Information Sciences, XLI-B6, 221-226. doi:10.5194/isprsarchives-XLI-B6-221-2016

9. 9. Forlani, G., Dall'Asta, E., Diotri, F., Cella, U. M. d., Roncella, R., \& Santise, M. (2018). Quality assessment of DSMs produced from UAV flights georeferenced with on-board RTK positioning. Remote Sensing, 10(2), 311.

10. Gianfranco, F., Elisa, D. a., Fabrizio, D., Umberto Morra Di, C., Riccardo, R., \& Marina, S. (2018). Quality Assessment of DSMs Produced from UAV Flights Georeferenced with On-Board RTK Positioning. Remote Sensing, 10(2), 311. doi:10.3390/rs10020311

11. Gindraux, S., Boesch, R., \& Farinotti, D. (2017). Accuracy Assessment of Digital Surface Models from Unmanned Aerial Vehicles' Imagery on Glaciers. Remote Sensing, 9(2), 186. doi:10.3390/rs9020186

12. Gong, C., Lei, S., Bian, Z., Liu, Y., Zhang, Z., \& Cheng, W. (2019). Analysis of the Development of an Erosion Gully in an Open-Pit Coal Mine Dump During a Winter Freeze-Thaw Cycle by Using Low-Cost UAVs. Remote Sensing, 11(11). doi:10.3390/rs11111356

13. Hugenholtz, C., Brown, O., Walker, J., Barchyn, T., Nesbit, P., Kucharczyk, M., \& Myshak, S. (2016). Spatial Accuracy of UAV-Derived Orthoimagery and Topography: Comparing Photogrammetric Models Processed with Direct Geo-Referencing and Ground Control Points. GEOMATICA, 70(1), 21-30. doi:10.5623/cig2016-102

14. Hugenholtz, C. H., Walker, J., Brown, O., \& Myshak, S. (2015). Earthwork Volumetrics with an Unmanned Aerial Vehicle and Softcopy Photogrammetry. Journal of Surveying Engineering, 141(1). 
15. Hugenholtz, C. H., Whitehead, K., Brown, O. W., Barchyn, T. E., Moorman, B. J., LeClair, A., ... Hamilton, T. (2013). Geomorphological mapping with a small unmanned aircraft system (sUAS): Feature detection and accuracy assessment of a photogrammetrically-derived digital terrain model. Geomorphology, 194, 16-24. doi:https://doi. org/10.1016/j.geomorph.2013.03.023

16. Le Van Canh, Cao Xuan Cuong, Le Hong Viet, \& Dinh Tien. (2020). Volume computation of quarries in Vietnam based on Unmanned Aerial Vehicle (UAV) data. Mining and earth sciences, 61(1), 21-30. doi:10.46326/ JMES.2020.61(1).03

17. Lee, S., \& Choi, Y. (2015). Topographic survey at small-scale open-pit mines using a popular rotary-wing unmanned aerial vehicle (drone). Tunnel \& Underground Space, 25, 462-469.

18. Mian, O., Lutes, J., Lipa, G., Hutton, J., Gavelle, E., \& Borghini, S. (2015). Direct georeferencing on small Unmanned Aerial platforms for improved reliability and accuracy of mapping without the need for ground control points. The International Archives of Photogrammetry, Remote Sensing and Spatial Information Sciences, xl(1), 397-402. doi:10.5194/isprsarchives-XL-1-W4-397-2015

19. Nguyen Quoc Long, Buczek, M. M., Szlapińska, S. A., Bui Xuan Nam, Nguyen Viet Nghia, \& Cao Xuan Cuong. (2018). Accuracy assessment of mine walls' surface models derived from terrestrial laser scanning. International Journal of Coal Science \& Technology, 5(3), 328-338.

20. Nguyen Quoc Long, Bui Xuan Nam, Cao Xuan Cuong, \& Le Van Canh. (2019). An approach of mapping quarries in Vietnam using low-cost Unmanned Aerial Vehicles. International Journal of Sustainable Development, 11(2):199210. doi:10.21177/1998-4502-2019-11-2-199-210

21. Nguyen Viet Nghia, Nguyen Quoc Long, Nguyen Thi Cuc, \& Bui Xuan Nam. (2019). Applied Terrestrial Laser Scanning for coal mine high definition mapping. World of Mining - Surface and Underground, 4(1613-2408), 237-242.

22. Siebert, S., \& Teizer, J. (2014). Mobile 3D mapping for surveying earthwork projects using an Unmanned Aerial Vehicle (UAV) system. Automation in Construction, 41, 1-14. doi:10.1016/j.autcon.2014.01.004

23. 23. Sona, G., Pinto, L., Pagliari, D., Passoni, D., \& Gini, R. (2014). Experimental analysis of different software packages for orientation and digital surface modelling from UAV images. Earth Science Informatics, 7(2), 97-107. doi:10.1007/s12145-013-0142-2

24. Štroner, M., Urban, R., Reindl, T., Seidl, J., \& Brouček, J. (2020). Evaluation of the Georeferencing Accuracy of a Photogrammetric Model Using a Quadrocopter with Onboard GNSS RTK. Sensors, 20, 2318. doi:10.3390/ s20082318

25. Taddia, Y., Stecchi, F., \& Pellegrinelli, A. (2020). Coastal Mapping using DJI Phantom 4 RTK in Post-Processing Kinematic Mode. Drones, 4, 9. doi:10.3390/drones4020009

26. Thiel, c., mueller, m., berger, c., cremer, f., dubois, c., hese, S., ... Pathe, C. (2020). Monitoring Selective Logging in a Pine-Dominated Forest in Central Germany with Repeated Drone Flights Utilizing A Low Cost RTK Quadcopter. Drones, 4. doi:10.3390/drones4020011

27. Vietnam Standards and Quality Institute. (2015). Vietnam Standards for Mine Surveying Hanoi: Vietnam Ministry of Industry and Trade.

28. Wiącek, P., \& Pyka, K. (2019). The test field for UAV accuracy assessments. ISPRS - International Archives of the Photogrammetry, Remote Sensing and Spatial Information Sciences, XLII-1/W2, 67-73. doi:10.5194/isprs-archivesXLII-1-W2-67-2019

29. Xuan-Nam, B., Nguyen, H., Hai-An, L., Hoang-Bac, B., \& Ngoc-Hoan, D. (2020). Prediction of Blast-induced Air Over-pressure in Open-Pit Mine: Assessment of Different Artificial Intelligence Techniques. Natural Resources Research, 29(2), 571-591. doi:10.1007/s11053-019-09461-0

30. Zhang, H., Aldana Jague, E., Clapuyt, F., Wilken, F., Vanacker, V., \& Oost, K. (2019). Evaluating the potential of post-processing kinematic (PPK) georeferencing for UAV-based structure- from-motion (SfM) photogrammetry and surface change detection. Earth Surface Dynamics, 7. doi:10.5194/esurf-7-807-2019 
Eksperymentalne badanie możliwości zastosowania UAV typu DJI Phantom 4 RTK $w$ trybie PPK do tworzenia $3 D$ modeli $w$ kopalniach odkrywkowych

Tereny kopalni odkrywkowych w Wietnamie są często pozbawione roślinności o silnie zróżnicowanej morfologii utworzone w wyniku eksploatacji górniczej. Tradycyjne prace geodezyjne w kopalniach odkrywkowych są czasochłonne. W artykule, przedstawiono wyniki badania dotyczacego procesu technologicznego generowania 3D modeli i ortofotomapy na podstawie danych pozyskanych $z$ pokładu bezzałogowej platformy UAV typu DJI Phantom 4RTK. Współcześne bezzałogowe statki powierzchne (BSP) stanowia dobrze rozwinięta gałąź lotnictwa, która umożliwia pozyskiwanie danych z pułapu od kilku do kilkuset metrów. Własność ta stwarza nowe możliwości zastosowanie UAV ww kopalniach odkrywkowych. Omawiano metodę połaczenia techniki fotogrametrii "Struktury z ruchu” (SfM) i fotogrametrii UAV, która jest szeroko stosowana w pomiarach topograficznych. Podczas gdy ważna rola naziemnych punktów kontrolnych (GCP) w dokładności cyfrowego modelu powierzchni (DSM) generowanego na podstawie obrazów uzyskanych przez "tradycyjne" UAV (a nie drony $z$ obstuga RTK) została udowodniona w wielu poprzednich badaniach, nie jest to jasne w przypadek dronów obsługujących RTK, zwłaszcza na skomplikowanym terenie w odkrywkowych kopalniach węgla. W tym badaniu eksperymentalnie zbadano wplyw GCP pod względem jego liczby i rozmieszczenia na dokładność generowania DSM na podstawie obrazów uzyskanych przez drony z obstuga RTK w odkrywkowych kopalniach węgla. Dodatkowo, tryb Post Processing Kinematic (PPK) zostat uruchomiony na polu testowym na tej samej wysokości lotu. Generowanie DSM przeprowadzono z kilkoma konfiguracjami sterowania blokami: tylko PPK, PPK z jednym GCP i PPK z dwoma GCP. Zbadano również kilka pozycji GCP, aby przetestować optymalne lokalizacje do umieszczania GCP w celu uzyskania dokładnych DSM. Wyniki pokazuja, że podana przez PPK dokładność pozioma $i$ pionowa wyniosła odpowiednio 9,3 i 84,4 cm. Jednak po dodaniu co najmniej jednego GCP dokładność została znacznie poprawiona zarówno w komponentach poziomych, jak i pionowych, przy RMSE dla XY i $Z$ w zakresie od 3,8 do 9,8 cm ( $z$ jednym GCP) i od 3,0 do 5,7 cm (z dwoma GCP), odpowiednio. Ponadto GCP umieszczone w głębokich obszarach kopalni odkrywkowej moga zapewnić dokładność w granicach centymetrowych (cm).

Słowa kluczowe: Bezzłagowe Statki Powietrzne, PPK, DSM, GCP i kopalnie odkrywkowe 